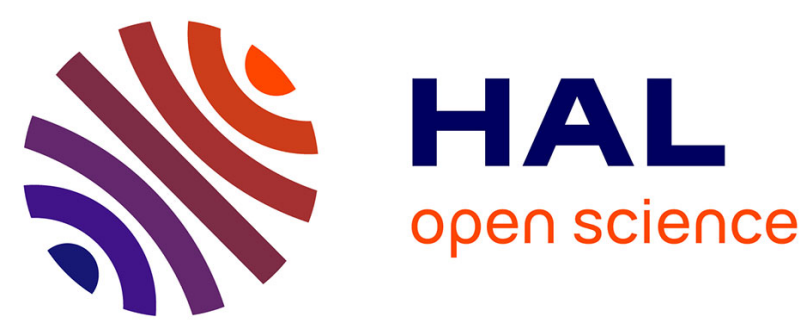

\title{
Effects of two offshore gas platforms on soft-bottom benthic communities (northwestern Adriatic Sea, Italy)
}

Sarine Manoukian, Alessandra Spagnolo, Giuseppe Scarcella, Elisa Punzo, Roberta Angelini, Gianna Fabi

\section{- To cite this version:}

Sarine Manoukian, Alessandra Spagnolo, Giuseppe Scarcella, Elisa Punzo, Roberta Angelini, et al.. Effects of two offshore gas platforms on soft-bottom benthic communities (northwestern Adriatic Sea, Italy). Marine Environmental Research, 2010, 70 (5), pp.402. 10.1016/j.marenvres.2010.08.004 . hal-00631680

\section{HAL Id: hal-00631680 \\ https://hal.science/hal-00631680}

Submitted on 13 Oct 2011

HAL is a multi-disciplinary open access archive for the deposit and dissemination of scientific research documents, whether they are published or not. The documents may come from teaching and research institutions in France or abroad, or from public or private research centers.
L'archive ouverte pluridisciplinaire HAL, est destinée au dépôt et à la diffusion de documents scientifiques de niveau recherche, publiés ou non, émanant des établissements d'enseignement et de recherche français ou étrangers, des laboratoires publics ou privés. 


\section{Accepted Manuscript}

Title: Effects of two offshore gas platforms on soft-bottom benthic communities (northwestern Adriatic Sea, Italy)

Authors: Sarine Manoukian, Alessandra Spagnolo, Giuseppe Scarcella, Elisa Punzo, Roberta Angelini, Gianna Fabi

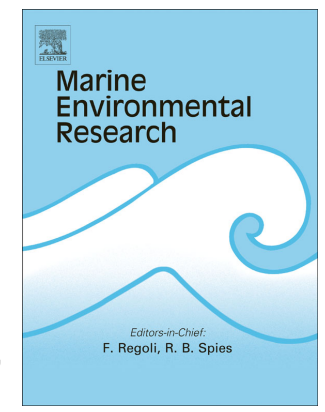

PII: S0141-1136(10)00119-4

DOI: 10.1016/j.marenvres.2010.08.004

Reference: MERE 3470

To appear in: Marine Environmental Research

Received Date: 23 February 2010

Revised Date: 13 August 2010

Accepted Date: 13 August 2010

Please cite this article as: Manoukian, S., Spagnolo, A., Scarcella, G., Punzo, E., Angelini, R., Fabi, G. Effects of two offshore gas platforms on soft-bottom benthic communities (northwestern Adriatic Sea, Italy), Marine Environmental Research (2010), doi: 10.1016/j.marenvres.2010.08.004

This is a PDF file of an unedited manuscript that has been accepted for publication. As a service to our customers we are providing this early version of the manuscript. The manuscript will undergo copyediting, typesetting, and review of the resulting proof before it is published in its final form. Please note that during the production process errors may be discovered which could affect the content, and all legal disclaimers that apply to the journal pertain. 


\section{ACCEPTED MANUSCRIPT}

1 Effects of two offshore gas platforms on soft-bottom benthic communities (northwestern

2 Adriatic Sea, Italy)

3 Sarine Manoukian ${ }^{1}$, Alessandra Spagnolo ${ }^{1}$, Giuseppe Scarcella ${ }^{1}$, Elisa Punzo ${ }^{1}$, Roberta Angelini ${ }^{2}$,

4 Gianna Fabi ${ }^{1 *}$

$5 \quad{ }^{1}$ CNR-Istituto di Scienze Marine, Sede di Ancona - Largo Fiera della Pesca, 60125 Ancona, Italy

$6 \quad{ }^{2}$ ENI SpA E\&P Division, Via del Marchesato 13, 48023 Marina di Ravenna, Italy

$7 \quad *$ Corresponding author: Tel.: +39 071 2078825; fax: +39 07155313

8 E-mail addresses: s.manoukian@ismar.cnr.it (Sarine Manoukian), a.spagnolo@ismar.cnr.it (Alessandra

9 Spagnolo), g.scarcella@ismar.cnr.it (Giuseppe Scarcella), e.punzo@an.ismar.cnr.it (Elisa Punzo), 10 roberta.angelini@eni.it (Roberta Angelini), g.fabi@ismar.cnr.it (Gianna Fabi)

Abstract

13 The macrozoobenthos living around two offshore gas platforms, Barbara NW (pB) and Calipso

$14(\mathrm{pC})$ located in the northwestern Adriatic Sea were investigated for three years after their 15 construction to detect eventual effects due to the platforms. The sampling stations were spaced at 16 increasing distance from the platforms up to $1000 \mathrm{~m}$. Both multivariate and univariate analysis 17 showed an initial defaunation (short-term effect) at $\mathrm{pB}$ and within a $120 \mathrm{~m}$ radius at $\mathrm{pC}$. A general recovery in terms of abundance, species richness and diversity was observed for the benthic communities after one year. During the third monitoring year a mussel mound developed at both the platforms (longer-term effect) extending up to $30 \mathrm{~m}$ from $\mathrm{pC}$, whereas similar soft-bottom

21 communities were found at all the other distances. The geographical position play an important role in the "timing" of the above effects. Moreover, despite the different environmental features, a 3-

23 year monitoring plan can be effective to evaluate the potential impact on benthic communities of offshore gas platforms in the north-central Adriatic Sea. 
1 Keywords: Offshore structures, Environmental impact, Zoobenthos, Community composition,

2 Adriatic Sea, Mussel mound. 


\section{Introduction}

Over the last 50 years, non-renewable resources exploitation has strongly increased to meet the global growing demand for energy. The offshore oil and gas industry plays a leading role in the marine field extraction activity exceeding 14 billion tonnes of oil equivalent (btoe; Ghisel, 1997; Pinder, 2001). In the Mediterranean basin, the Italian production of natural gas was 11.4 million tonnes of oil equivalent (mtoe) in 2004, rising to 0.2 btoe in 2005, the fourth-largest in the EU. About $80 \%$ of the total energy comes from this type of activity (Brighenti et al., 2003), and almost half of it is provided from offshore reserves in the Adriatic continental shelf (OGP, 2005). More than 110 offshore gas platforms have been deployed since the 1960s in the northern and central parts of this basin (Maggi et al., 2007), representing the highest concentration of fossil fuel extraction platforms in the Mediterranean area.

It is well known that drilling operations generate waste fluids and cuttings that could cause strong environmental impacts related to drilling mud discharges or hydrocarbons associated waters (Terlizzi et al., 2008). Moreover, the physical structure of the platform may modify local water flow and alter sediment type, affecting the benthic community composition (Wilson-Ormond et al., 2000). Generally, during the installation phase and the drilling operations, benthic communities closer to the platforms show a decrease in diversity and a change in species' abundance, while further away, assemblages may appear more similar to those in the surrounding unaffected area (Grant and Briggs, 2002).

The radius of impact can be different depending on the number of platforms placed in a restricted area, the structures' dimensions and biogeographic/climatic factors. For example, in the North Sea a few studies found effects up to $3,000 \mathrm{~m}$, with more severe impacts within a $500 \mathrm{~m}$ radius (Gray et al., 1999; Kingston, 1987; Olsgard et al., 1997). In the Gulf of Mexico the long-term effects of oil-related activities on the benthos were evident up to $200 \mathrm{~m}$ from the source and up to $800 \mathrm{~m}$ from produced water discharge points (Hernández Arana et al., 2005; Montagna and Harper, 1996; Peterson et al., 1996; Rabalais et al., 1992). 
The water-based drill-cuttings, commonly used in the Adriatic Sea, are less toxic than oil-

2 based drilling muds (Cameron et al., 2004; Olsgard and Gray, 1995). Moreover, in most of cases neither drill-cuttings nor formation water are discharged at sea during the drilling operations.

However, structures' installation, drilling operations as well as the associated great occurrence of ships can cause an increase of metals, hydrocarbons and other chemical agents in the environment causing potential impacts to the surrounding physical and biotic compartments.

Some studies highlighted the effects of platforms on benthic communities over the time (Fabi et al., 2007; Frascari et al., 1991, 1992; Spagnolo et al., 2002, 2006; Trabucco et al., 2006). In most of these cases, the more relevant ecological alteration due to the presence of a gas platform was a mussel mound development affecting the surrounding seabed communities within a radius of 11 a few meters.

However, there is still much research to be undertaken to fully understand the gas platforms' potential impacts on the surrounding zoobenthos in the Adriatic Sea. Nevertheless, these platforms are installed in a wide variety of environments, with different types of sediments (from mud to sand) that may be under the influence of rivers such as the Po River representing the main source of fresh water into the northern Adriatic Sea (Cattaneo et al., 2003; Grilli et al., 2005; Marini et al., 2008). This situation, associated with the high drilling activity in the Adriatic basin, makes it difficult to develop general models for prediction of offshore platforms' impact.

The present work compares the possible effects on the surrounding zoobenthic communities of two 4-leg gas platforms (Barbara NW and Calipso) in the northwestern Adriatic Sea installed at similar depth but at different distances from the coastline and different types of seabed. It represents an approach to detect possible common impact patterns both in temporal and spatial terms.

Data were collected in the framework of a wider monitoring programme aimed to evaluate the impacts of the platforms' installation on the different components of the marine environment 
2. Materials and Methods

\subsection{Study area}

The Adriatic Sea is a small continental shelf about $800 \mathrm{~km}$ long in NW-SE direction and about $200 \mathrm{~km}$ wide. The northern part of the basin is very shallow, rarely exceeding $46 \mathrm{~m}$ depth, while in the central part the depth can reach $80 \mathrm{~m}$. The continental slope located around $600 \mathrm{~km}$ from the northern limit separates the central Adriatic from the southern one where the depth reaches 1,200 $\mathrm{m}$. The northern basin receives a high nutrient input from Po River and other minor streams which enhances primary production near the surface and oxygen demand near the bottom (Grilli et al., 2005; Marini et al., 2008). The Po watershed is very large and includes densely populated regions (Crema et al., 1991).

The study was conducted in the northwestern Adriatic Sea. Two 4-leg offshore gas monitored for three years.

$\mathrm{pB}$ is located on a muddy sand seabed at a mean depth of $68.5 \mathrm{~m}, 56 \mathrm{~km}$ off Ancona (De measured during the study period fluctuated between Northwest and Southeast and had a speed distances from the platform. Heavy metal content in the sediments did not show significant changes

21 at increasing distance from the platform, except for some peaks of cadmium, zinc, mercury, and lead recorded in the surroundings of the structure during the first monitoring year after installation. These anomalies gradually disappeared in the subsequent years (De Biasi et al., 2008; Fabi et al., 2005). Polycyclic Aromatic Hydrocarbon (PAH) levels increased in the second monitoring year (2001) and strongly declined at the end of 2002. However, with only a few exceptions, the values of the above contaminants usually agreed with those reported in other areas of the Adriatic Sea 
1 (Guerzoni et al., 1984; Magi et al., 2002). Organic matter always showed the highest

2 concentrations close to the platform and gradually decreased with increasing distances from it,

3 indicating an intense biological activity around the structure (unpublished results).

$\mathrm{pC}$ is located on a muddy seabed approximately $35 \mathrm{~km}$ off Ancona in $75 \mathrm{~m}$ of water (De

5 Biasi et al., 2007; Fig. 1). The structure was installed in May 2002 and the drilling operations

6 started in the following month and finished in October 2002. Production began immediately

7 thereafter. Again, six field cruises were carried out from 2003 to 2005 (two per year). During the study period the main current at the sea bottom flowed from Northwest towards Southeast,

9 following the basin topography with a speed of 5-10 $\mathrm{cm} \mathrm{s}^{-1}$ sporadically reaching $20 \mathrm{~cm} \mathrm{~s}^{-1}$

10 (Paschini, unpublished results). The sediment texture was homogeneous at the different distances

11 from the platform in the overall study period. A gradual decrease of heavy metal content was 12 observed from the first to the last monitoring year. Nevertheless, some anomalies for copper, lead, barium and zinc were recorded during the overall monitoring period. During the first two years after installation PAH concentrations were higher around the structure compared with those recorded at the farther distances, but they decreased in 2005 (De Biasi et al., 2006, 2007). Also in this case the recorded contaminant levels were comparable with those reported in other Adriatic areas (Guerzoni et al., 1984; Magi et al., 2002). Organic matter content was homogeneous in the overall area, showing a consistent increase in the second monitoring year which persisted until the end of 2005

19 (De Biasi et al., 2007).

At both platforms water-based muds were used for the drilling operations and neither cuttings nor formation waters were discharged at sea. Moreover, no water is discharged during the production phase.

\section{$23 \quad 2.2$ Sampling design and analyses}

The sampling design was planned according to the 'gradient design' approach that is particularly useful when a stressor or disturbance attenuates with the distance from the point source of impact (Ellis and Schneider, 1997). 
For each platform, four sampling sites (about $20 \mathrm{~m}$ apart) were randomly selected at $5 \mathrm{~m}, 30$

$2 \mathrm{~m}, 60 \mathrm{~m}, 120 \mathrm{~m}$, and $1000 \mathrm{~m}$ from the structure. At each site three samples were collected using a

3 Van-Veen grab (capacity $=13 \mathrm{~L}$ and width $=0.105 \mathrm{~m}^{2}$ ), for a total of 12 samples for each selected 4 distance.

The overall 720 biological samples (60 samples x 2 platforms x 6 surveys) were sieved in

6 situ through a $0.5 \mathrm{~mm}$ mesh and all organisms retained were preserved in $5 \%$ buffered formalin. In

7 the laboratory, macrofauna was sorted through a stereomicroscope and a binocular microscope, identified and classified to the species level when possible using standard nomenclature, quantified,

9 and weighted.

\subsection{Data analysis}

Multivariate analyses were performed to identify spatial and temporal changes in the composition and abundance of macrofauna communities using PRIMER ${ }^{\mathrm{TM}}$ ecological software package developed by the Plymouth Marine Laboratory (Clarke, 1993; Clarke and Warwick, 2001). Prior to any analysis, the species abundance data were fourth-root transformed to reduce the contribution of prevalent taxa and therefore increase the importance of less abundance species. Afterwards, species contributing at least $10 \%$ of the total community abundances were selected and the Gower exc 0-0 similarity matrix was calculated. Gower coefficient is well-suited for quantitative abundance data excluding double-zeros from comparison (Legendre and Legendre, 1998). The differences among macrofauna assemblages at increasing distance from platforms during the three monitoring years were tested by means of a permutation analysis of variance. This method allowed testing of the general multivariate hypothesis of differences in the composition and/or relative abundances of organisms of different species in samples from different groups

23 (Anderson, 2001; McArdle and Anderson, 2001). In the 3-way PERMANOVA, Distance (five levels fixed factor), Year (three levels fixed factor) and Platform (two levels random factor orthogonal to the other two factors) were considered. Since the test results were significant for the factor Platform, $\mathrm{pB}$ and $\mathrm{pC}$ were investigated separately and independently from each other. 
For both $\mathrm{pB}$ and $\mathrm{pC}$, multivariate patterns of variation among distances and years were

2 tested by PERMANOVA and the significant terms were investigated using pair-wise comparisons.

3 Successively, similarity percentage breakdown procedure (SIMPER; Clarke and Warwick, 2001)

4 was used to determine the contribution of individual taxa towards the dissimilarity between and

5 similarity within the two distance and year groups.

Univariate measures such as species abundance $(\mathrm{N})$, species richness $\left(\mathrm{S}_{\mathrm{m}}\right)$ and Simpson

7 index ( $\lambda$; Simpson, 1949) were calculated on benthic abundance data for each sampling site at each distance for the three sampling years. Changes in these biological indices were examined using the same statistical design previously described for PERMANOVA. The random factor Platform and/or

10 the interactions between Platform and the other terms showed again significant differences.

11 Therefore a 2-way ANOVA was conducted separately for each platform considering Distance and

12 Year as fixed factors. In the case of significant interactions, a one-way ANOVA was employed for each temporal factor level to compare the distance. Prior to performing statistical analyses, normal

14 distribution and heterogeneity of variances were evaluated through the Kolmogorov-Smirnov and 15 Bartlett tests, respectively (Lindman, 1992). When the latter was significant, the relationship 16 between means and the respective standard deviations was analysed to check whether the ANOVA 17 assumptions were effective at any rate. Based on the tests, total abundance data $(\mathrm{N})$ were logtransformed. The Tukey HSD test for balanced samples was used to make comparisons across all

19 pairs of group means when corresponding ANOVA tests were significant. Levels of significance 20 were set at $\mathrm{p} \leq 0.01$ (highly significant) and $\mathrm{p} \leq 0.05$ (significant).

\section{Results}

\subsection{Overview}

A total of 206 taxa were recorded at pB. This group included 92 polychaetes, 52 crustaceans, 41 molluscs, 8 echinoderms, 5 cnidarians, 3 sipunculids, 1 ascidian, 1 nemertean, 1 
nematod, 1 platelmint and 1 tunicate, for a total of 1,369 ind $0.105 \mathrm{~m}^{-2}$. The community mostly consisted of both limicoulus and sandy organisms.

On the other hand, a total of 139 taxa were found at pC. Of these, polychaete worms made up again the greatest proportion of the macroinvertebrate population with 67 taxa, followed by 32 crustaceans, 26 molluscs, 6 echinoderms, 4 cnidarians, 2 sipunculids, 1 nemertean and 1 platelmint, for a total of 1,481 ind $0.105 \mathrm{~m}^{-2}$. Limicoulus species dominated the community.

Although at both $\mathrm{pB}$ and $\mathrm{pC}$ sites most taxa were typical of soft-bottom communities, close to the platforms, hard-bottom species were also found, especially crustaceans (e.g., Pilumnus hirtellus, Galathea intermedia) and molluscs (e.g., Mytilus galloprovincialis, Neopycnodonte cochlear, Hiatella arctica). Although the number of these species was initially very low in all the sampling sites, it increased by the end of the monitoring (during the third year) at both $\mathrm{pB}$ and $\mathrm{pC}$.

\subsection{Multivariate patterns}

The 3-way PERMANOVA highlighted a significant difference in the abundance of macrobenthos between $\mathrm{pB}$ and $\mathrm{pC}$ (Table 1). Moreover, significant interactions among Distance, Year and Platform were shown by PERMANOVA (Table 1). Analyzing separately the two platforms, significant differences among distances and years were found for both $\mathrm{pB}$ and $\mathrm{pC}$ (Table 2 ), indicating a potential effect of the platforms on the spatial and temporal variation of zoobenthic communities. Pair-wise test revealed that $5 \mathrm{~m}$ sites for $\mathrm{pB}$ were different from all the other distances during the overall sampling period (Table 2), while the $1000 \mathrm{~m}$ sites were different from all the others only during the first sampling year. A spatial gradient was determined by the presence of the platform from sites nearest to the platform to those furthest away. The macrofauna assemblages evolved in the second and third year. The communities became similar at all distances with the exception of $5 \mathrm{~m}$ sites. On the other hand, as regards $\mathrm{pC}$, pair-wise tests pointed out a temporal evolution of $5 \mathrm{~m}$ sites which became completely different from all the other sites in the last sampling year (Table 2). 
SIMPER analysis showed the highest dissimilarities between $5 \mathrm{~m}$ sites and all the other

2 distances for both $\mathrm{pB}$ and $\mathrm{pC}$ (Table 3). The crustacean Callianassa subterranea, together with the polychaetes Nephtys hystricis, Capitella capitata, and Paralacydonia paradoxa were not collected in $5 \mathrm{~m}$ sites for $\mathrm{pB}$ and were the major contributors to these dissimilarities.

On the other hand, the decrease of abundant polychaete species such as Caulleriella caputesocis, Sternaspis scutata, and Prionospio cirrifera was associated with a greater contribution of the polychaetes Marphysa bellii, Lumbrineris impatiens, of the gastropod Hyala vitrea, and of $C$. subterranea at increasing distance from the platform. These species were the major ones responsible for the differences at $\mathrm{pC}$.

On temporal scale (year groups, Table 3) the dissimilarity was slightly higher between the second and third years rather than between the first and the second ones for $\mathrm{pB}$, while highly decreased for $\mathrm{pC}$.

\subsection{Univariate patterns}

As in the multivariate analysis, also the 3-way ANOVA highlighted highly significant interactions among the three considered factors (Distance, Year, and Platform; Table 4). Therefore, community was represented everywhere by a low number of both species and individuals. $\mathrm{S}_{\mathrm{m}}$ (Fig. 2) changed from $4.63 \pm 1.03(5 \mathrm{~m})$ to $14.50 \pm 3.37$ (1000 m; one-way ANOVA, $p<0.01)$. A significant increment $(p<0.05)$ was observed from $5 \mathrm{~m}$ to $30 \mathrm{~m}$, which showed a value of $13.38 \pm 1.64$ similar to all the other distances. No differences among distances were recorded for $\mathrm{N}$, varying from 12.00 \pm 1.55 ind $0.105 \mathrm{~m}^{-2}(5 \mathrm{~m})$ and $27.38 \pm 5.16$ ind $0.105 \mathrm{~m}^{-2}(60 \mathrm{~m} ;$ Fig. 2). In contrast, the $\lambda$ value at $5 \mathrm{~m}(0.38 \pm 0.0 .30)$ was significantly higher than the others $(p<0.01)$ due to the dominance of the polychaete Prionospio malmgreni. In the second year, $\mathrm{S}_{\mathrm{m}}$ and $\mathrm{N}$ were characterized by similar 
1 recorded at $5 \mathrm{~m}$. The difference was significant only for $S_{\mathrm{m}}$ in respect to $30 \mathrm{~m}(19.13 \pm 1.55$;

$2 p<0.05)$. At the end of the second monitoring year, a mussel mound started to develop close to the

3 platform hosting a varied macrobenthic community composed by both soft- and hard-bottom

4 species. As a consequence, during the third year, $S_{m}$ and $N$ reached the highest values $(23.25 \pm 6.74$

5 and $104.00 \pm 31.25$ ind $0.105 \mathrm{~m}^{-2}$ respectively) at $5 \mathrm{~m}$, showing significant differences with the other

6 distances. $\lambda$ was similar everywhere due to the high number of species with low dominance.

$\mathrm{S}_{\mathrm{m}}, \mathrm{N}$, and $\lambda$ showed different spatial trends in each year also for $\mathrm{pC}$, making significant the interaction between Distance and Year (Table 5). In the first sampling year the benthic community living just close to the platform up to $1000 \mathrm{~m}$ was very poor in terms of number of both individuals and species. The highest value of $\lambda$ was recorded at $5 \mathrm{~m}(0.55 \pm 0.39)$ and the lowest at $1000 \mathrm{~m}$ $(0.16 \pm 0.05$; Fig. 2).The only significant differences $(p<0.05)$ were observed between $5 \mathrm{~m}$ and 1000 $\mathrm{m}$ for both $\mathrm{S}_{\mathrm{m}}\left(3.38 \pm 0.98\right.$ and $11.50 \pm 2.95$ respectively) and $\mathrm{N}\left(7.50 \pm 1.65\right.$ ind $0.105 \mathrm{~m}^{-2}$ and $36.88 \pm 15.44$ ind $0.105 \mathrm{~m}^{-2}$ respectively). During the second year all the three indices did not show any spatial trend and all the values were similar to each other (Fig. 2). Also in this case a mussel mound developed at the end of the second monitoring year but differently from $\mathrm{pB}$, it extended up to $30 \mathrm{~m}$ from the platform. As a consequence, $\mathrm{S}_{\mathrm{m}}$ and $\mathrm{N}$ increased within this area in the last sampling period. Some hard-bottom species (e.g., N. cochlear, Ostrea edulis, Modiolarca subpicta), not observed at the other distances, in fact, were recorded in addition to the typical soft-bottom taxa. The values of $S_{\mathrm{m}}$ obtained within a $30 \mathrm{~m}$ radius were similar to each other $(5 \mathrm{~m}: 23.00 \pm 3.32 ; 30 \mathrm{~m}$ : 22.13 \pm 2.10 ) and significantly higher than those observed from 120 up to $1000 \mathrm{~m}$ ( $p<0.05$; Fig. 2).

21 The greater occurrence of $M$. galloprovincialis at $5 \mathrm{~m}$ caused a very high $\mathrm{N}$ value close to the platform $\left(243.50 \pm 33.15\right.$ ind $\left.0.105 \mathrm{~m}^{-2}\right)$, which was statistically different from the other distances 23 ( $p<0.01)$. Also the $30 \mathrm{~m}$ value $\left(87.00 \pm 9.87\right.$ ind $\left.0.105 \mathrm{~m}^{-2}\right)$ was significantly higher than those recorded at the further distances $(p<0.01)$. Finally, $\lambda$ index was significantly higher at $5 \mathrm{~m}$ $(0.20 \pm 0.06)$ in comparison to $30 \mathrm{~m}$ and $60 \mathrm{~m}(p<0.01$ and $p<0.05$ respectively). 
The Adriatic Sea is largely affected by many different human activities (e.g., tourism,

3 fishing, open-sea aquaculture), and the extraction of natural gas represents one of the most

4 important. The quantification and interpretation of the environmental effects of offshore gas 5 platforms can be difficult and hard to generalize. Although the physical presence of the structure is 6 a common characteristic to all the platforms, several local abiotic and biotic variables, especially in 7 the Adriatic Sea, influence the effects of each platform in a unique and different way. In fact, the peculiar physiography of this long, narrow, shallow water basin with many fresh water inputs, enhances the effects of nutrients and oxygen concentration, salinity, temperature, turbidity, currents, primary and secondary production (Grilli et al., 2005; Marini et al., 2008).

The natural sea bottom in most areas proposed for offshore gas platforms in the Adriatic shelf consists of soft sediments ranging from coastal mud to offshore coarse sand inhabited by an adapted fauna. Many benthic organisms are sessile, and can hardly escape natural and anthropogenic disturbances. In addition, several species are known to be susceptible to disturbances or environmental changes. Due to their sessile character and ability to "integrate" environmental influences over longer time scales, these species are commonly regarded as good indicators for environmental impacts (Underwood, 1996), as well as for long-term changes in the ecosystem (Kröncke, 1995).

This study assesses and compares the possible effects of two gas platforms located in the north-western Adriatic Sea on the surrounding benthic communities. The aim is to find a common

21 pattern in the populations' response to the installation of Adriatic offshore structures and identify the ecological features mostly leading the macrofauna changes. The two platforms are quite similar

23 in shape and dimensions, but located at different distances from the coast. Consequently, according to grain size distribution maps (George et al., 2007; Harris et al., 2008) and water circulation pattern in the northwestern Adriatic basin, they are situated on different sediment types (De Biasi, unpublished results; De Biasi et al., 2007) and subjected to different environmental variables. 
1 Bottom currents, river plumes, and turbidity, for example, tend to decrease from the coast towards

2 offshore (Boldrin et al., 2009).

Some differences in the composition of the benthic communities recorded in the surroundings of the two platforms may be associated with the diverse sediment texture. Limicoulus organisms, indeed, were found around $\mathrm{pC}$, whereas a mix of sandy and limicoulus species characterized pB. These differences in the benthic communities living in the natural habitats as well as the distance from the coast and other abiotic features (i.e. currents, river plumes, and turbidity) could explain the different response to the impacts caused by the platforms' installation and drilling operations. Distance from the coast was found to be one of the main factors affecting metal distribution around offshore platforms in the western Adriatic Sea (De Biasi et al., 2008). In

11 addition, a strong relationship between changes in benthic communities and decreasing gradients of contaminants' concentration at increasing distance from the platforms was reported by Olsgard and Gray (1995). As regards $\mathrm{pC}$ and $\mathrm{pB}$, the results of sediment analysis did not show significant levels of contamination, suggesting a minor role of chemical pollution in determining the observed gradients of variation in benthic assemblages (De Biasi et al., 2006, 2007, 2008). Similar findings were also reported by Terlizzi et al. (2008) for inshore and offshore platforms located in the Ionian Sea.

The zoobenthos close to $\mathrm{pB}$ was different from that living at the various distances from the platform in the overall survey period. During the first year, indeed, just after the end of the drilling operations, the community at $5 \mathrm{~m}$ was very poor especially in terms species number and strongly dominated by the opportunistic polychaete $P$. malmgreni, typical of defaunated, organic matter enriched areas, and also living in polluted habitats ( $\mathrm{Lu}$ and $\mathrm{Wu}, 2000$; Pearson and Rosemberg, 1978). The great occurrence of this species agreed with the high level of organic matter observed at that time close to the platform (unpublished results). From $30 \mathrm{~m}$ to $120 \mathrm{~m}$ apart some soft-bottom species not observed at $1000 \mathrm{~m}$ were found. Some of these taxa were suspension- or deposit feeders (e.g., Onuphis conchilega), likely attracted to this area by detritus and microparticulate matter made 
available by the bottom mixing due to the drilling operations. Other taxa were carnivorous (e.g.,

2 Alpheus glaber) foraging on the above mentioned species. This scenario indicates a more severe effect just close to the platform and a slight influence on the surrounding seabed restricted to $120 \mathrm{~m}$, likely due to the weak bottom currents characterizing the area (Fabi et al., 2005).

A different situation was observed for $\mathrm{pC}$ where an initial defaunation in terms of number of species and individuals was observed up to $120 \mathrm{~m}$. This wider spreading out of the impact may be attributed to the more intensive bottom currents compared to $\mathrm{pB}$ (Paschni, unpublished results). Some opportunistic species were found within $120 \mathrm{~m}$ of radius (e.g., C. caputesocis, P. cirrifera) acting as pioneers in defaunated bottoms and preparing the substrate for other organisms' colonization which have more elaborate settlement needs (Pearson and Rosemberg, 1978).

In the second sampling year the benthic communities living close to the platforms showed a recovery from the previous defaunation. The appearance and/or the abundance increase of some common soft-bottom species (e.g., O. conchilega for $\mathrm{pB}$ and $H$. vitrea, $M$. bellii for $\mathrm{pC}$ ) were recorded at all the distances. Moreover, in the case of $\mathrm{pB}$ a reduction of $P$. malmgreni was $\mathrm{m}$ for $\mathrm{pB}$ and up to $30 \mathrm{~m}$ for $\mathrm{pC}$. This process made $5 \mathrm{~m}$ for both platforms and $30 \mathrm{~m}$ for $\mathrm{pC}$ again different from the other distances in terms of either number of species, number of organisms and 
1 dead specimens as shelter (Kneib and Weeks, 1990; Warburg and Schwartz, 1993; Zariquiey

2 Alvarez, 1968). Some sessile species, instead, settle on the mussel shells utilizing them as substrate.

3 As a consequence of above, hard bottom organisms, attracted by the mussels, enrich the community

4 (Bomkamp et al., 2004; Page et al., 1999; Thayer et al., 1997; Wolfson et al., 1979). This scenario

5 is common in the northern and central Adriatic Sea and it was already observed at other offshore

6 platforms located at different depths and distances from the coastline (Fabi et al., 2007; Spagnolo et

7 al., 2002, 2006; Trabucco et al., 2006, 2008). Formation of mussel mounds, increased substrate heterogeneity, and development of hard bottom communities close to the offshore platforms have been also reported in southern California (Love et al., 1999; Page et al., 1999; Wolfson et al., 1979), in the southern Arabian Gulf (Stachowitsch et al., 2002), and in the south-eastern Australia (Currie and Isaacs, 2005). An enrichment of the benthic macrofauna up to $100 \mathrm{~m}$ from the platform, mainly due to the increase of deposit-feeding polychaetes, was also observed by Montagna and Harper (1996) in the Gulf of Mexico.

In conclusion, two main typologies of effects on soft-bottom benthic communities were observed for both $\mathrm{pB}$ and $\mathrm{pC}$. An initial short-term ( one year), localized effect, consisting in the defaunation, may be attributed to the installation of the platforms and drilling operations. A following longer-term effect bound to the physical presence of the structures started at the end of the second year after installation and consisted of the development of mussel mounds and the subsequent macrofauna enrichment/diversification close to the platforms.

Geographical position likely plays an important role in the "timing" of the above effects. In

21 the case of platforms placed in shallower water close to the western Adriatic coast (less than 20 $\mathrm{km}$ ), all the potential effects appeared accelerated. In fact, the recovery of natural soft-bottom communities from the initial defaunation and the mussel mound's development started 7-8 months and about 1.5 years after the drilling operations, respectively (Fabi et al., 2005, 2007; Spagnolo et al., 2002, 2006). The higher variability of the environmental parameters and the frequent sediment mixing due to sea storms and currents typical of these near shore areas seem to be the main factors 
1 that induced a major population dynamic reducing all the effects' duration. As a matter of fact, a

2 slight difference in the time of recovery was also highlighted between $\mathrm{pC}$ and $\mathrm{pB}$, located at similar depth but $35 \mathrm{~km}$ and $56 \mathrm{~km}$ offshore respectively.

The homogeneity observed from $30 \mathrm{~m}$ up to the farther distances from the platforms during

5 the third sampling year after installation agrees with what was previously reported for other

6 offshore structures located in the same area (Fabi et al., 2005, 2007; Spagnolo et al., 2002, 2006)

7 and indicates that, despite the different environmental features, a 3-year monitoring planning can be effective to evaluate the potential impact on benthic communities of offshore gas platforms in the north-central Adriatic Sea.

From the ecological point of view, the increased seabed heterogeneity due to shells,

11 fragments and dead organisms falling for natural dislodgement or structure cleaning, associated to

12 the physical extension along the water column, make the platforms a unique habitat. Many aquatic 13 organisms, indeed, can settle on these substrates or gather around them either for orientation, 14 protection and/or greater food availability (e.g., Bomkamp et al., 2004; Fabi et al., 2004; Neira, 15 2005; Page et al., 1999, 2007; Stanley and Wilson, 1997; Wolfson et al., 1979). As a consequence, 16 after the first impact caused by the installation and drilling operations, the offshore platforms can 17 play an important ecological role in areas characterized by flat soft bottoms and relatively small 18 amount of natural reef habitat like the Adriatic Sea, inducing a diversification and an enrichment of 19 both the natural benthic and finfish communities. 
Acknowledgements

2 Authors acknowledge ENI S.p.A. - E\&P Division for the financial aid and the technical support

3 during the whole period of work. Many thanks also to the staff of Marine Environment

4 Management Unit of ISMAR Ancona and the crew of the R/V "Tecnopesca II" who actively

5 contributed to the data recording.

\section{References}

Anderson, M.J., 2001. A new method for non-parametric multivariate analysis of variance. Australian Ecology 26, 32-46.

Anderson, M.J., Willis, T.J., 2003. Canonical analysis of principal coordinates: a useful method of constrained ordination for ecology. Ecology 84, 511-525.

Boldrin, A., Carniel, S., Giani, M., Marini, M., Bernardi Aubry, F., Campanelli, A., Grilli, F., Russo, A., 2009. Effects of bora wind on physical and biogeochemical properties on stratified waters in the northern Adriatic. Journal of Geophysical Research 114, C08S92, doi:10.1029/2008JC004837.

Bomkamp, R.E., Page H.M., Dugan, J.E., 2004. Role of food subsidies and habitat structure in influencing benthic communities of shell mounds at sites of existing and former offshore oil platforms. Marine Biology 146, 201-211.

Brighenti, G., Macini, P., Mesini, E., 2003. Environment and sustainable management of hydrocarbons. Proc. 4th European Congress on Regional Geoscientific Cartography and Information Systems I, 69-71.

Cameron, C., Florence, A., Temple, C., 2004. Water-based drilling fluid helps achieve oil-mud performance. American Association of Drilling Engines, 1-6.

Cattaneo, A., Correggiari, A., Langone, R., Trincardi, F., 2003. The late-Holocene Gargano subaqueous delta Adriatic shelf: sediment pathways and supply fluctuations. Marine Geology 193, 61-91. 
1 Clarke, K.R., 1993. Non-parametric multivariate analyses of changes in community structure. Australian Journal of Ecology 18, 117-143.

Clarke, K.R., Warwick, R.M., 2001. Change in marine communities: an approach to statistical analysis and interpretation. Plymouth Marine Laboratory, UK.

Crema, R., Caselli, A., Prevedelli, D., 1991. Long term eutrophication effects on macrofaunal communities in Northern Adriatic Sea. Marine Pollution Bulletin 22, 503-508.

Currie, D.R., Isaacs, L.R., 2005. Impact of exploratory offshore drilling on benthic communities in the Minerva gas field, Port Campbell, Australia. Marine Environmental Research 59, 217233.

De Biasi, A.M., Pacciardi, L., Fabi, G., 2008. Effetti di alcune variabili nominali sui metalli pesanti di otto piattaforme estrattive nel Mar Adriatico. Biologia Marina Mediterranea 15(1), 416417.

De Biasi, A.M., Fabi, G., Pacciardi, L., Puletti, M., 2007. Heavy metals and polycyclic aromatic hydrocarbons near an offshore gas-platform (Adriatic Sea): a 3 year monitoring study. Atti Società Toscana Scienze Naturali, Memorie, Serie B 114, 23-33.

De Biasi, A.M., Fabi, G., Pacciardi, L., Spinelli, O., Micheli, R., Puletti, M., De Ranieri, S., 2006. Metalli pesanti e idrocarburi policiclici aromatici in prossimità di una piattaforma di estrazione: 3 anni di osservazioni (Adriatico settentrionale). Biologia Marina Mediterranea 13(2), 332-333.

Ellis, J.I., Schneider, D.C., 1997. Evaluation of a gradient sampling design for environmental impact assessment. Environmental Monitoring Assessment 48, 157-172.

Fabi, G., Ausili, S., Campanelli, A., De Biasi, A., Fornasiero, P., Grati, F., Grilli, F., Marini, M., Panfili, M., Paschini, E., Puletti, M., Scarcella, G., Spagnolo, A., 2005. Evaluation of the ecological impact of gas platforms in the Adriatic Sea. Libro de Ponencias II Congreso Internacional de Ciencia y Tecnología Marina - Oceanos III Millennium Tomo I. Editorial C.P.D., Madrid, 127-139. 
1 Fabi, G., Da Ros, L., De Biasi, A.M., Manoukian, S., Nasci, C., Puletti, M., Punzo, E., Spagnolo, A., 2007. Environmental impact of gas platforms in the Northern Adriatic Sea: a case study. Rapport de la Commission Internationale pour l'Exploration Scientifique de la Mer Méditerranée 38, 471.

Fabi, G., Grati, F., Puletti, M., Scarcella, G., 2004. Effects on fish community induced by the installation of two gas platforms in the Adriatic Sea. Marine Ecology Progress Series 273, 187-197.

Frascari, F., Rosso, G., Bortoluzzi, G., Barbanti, A., Ravaioli, M., Bonvicini Pagliai, A.M., Crema, R., Castelli, A., Mauri, M., Zunarelli, R., Orlando, E., Prevedelli, D., Ceffa, L., Ratti, S., 1991. Uno studio sull'impatto dell'attività di perforazione in ambiente marino. Atti della Societá Italiana di Ecologia (S.It.E.) 12, 761-767.

Frascari, F., Rosso, G., Bortoluzzi, G., Barbanti, A., Bonvicini Pagliai, A.M., Crema, R., Castelli, A., Mauri, M., Zunarelli, R., Orlando, E., Prevedelli, D., Ceffa, L., Ratti, S., 1992. Environmental impact of water based drilling muds and cuttings in a northern Adriatic Sea site. Bulletin de l'Institut Océanographique, Monaco 11, 305-324.

George, D.A., Hill, P.S. and Milligan, T.G., 2007. Flocculation, heavy metals $(\mathrm{Cu}, \mathrm{Pb}, \mathrm{Zn})$ and the sand-mud transition on the Adriatic continental shelf, Italy. Continental Shelf Research 27, 475488.

Ghisel, R.G., 1997. Years of Offshore Oil, Gas Development. Hart Publications, Houston.

Grant, A., Briggs, A.D., 2002. Toxicity of sediments from around a North Sea oil platform: are metals or hydrocarbons responsible for ecological impacts? Marine Environmental Research $53,95-116$.

Gray, J.S., Bakke, T., Beck, H.J. Nilssen, I., 1999. Managing the environmental effects of the Norwegian oil and gas industry: from conflict to consensus. Marine Pollution Bulletin 38, $525-530$. 
1 Grilli, F, Marini, M., Degobbis, D., Ferrari, C.R., Fornasiero, P., Russo, A., Gismondi, M., Djakovac, T., Precali, R., Simonetti, R., 2005. Circulation and horizontal fluxes in the northern Adriatic Sea in the period June 1999-July 2002. Part II: Nutrients transport. Science of the Total Environment 353, 115-125.

Guerzoni, S., Frignani, M., Giordani, P., Frasari, F., 1984. Heavy metals in sediments from different environments of a northern Adriatic Sea area, Italy. Environmental Geology and Water Sciences 6, 111-119.

Harris, C.K., Sherwood, C.R., Signell, R.P., Bever, A.J. and Warner, J.C., 2008. Sediment dispersal in the northwestern Adriatic Sea. Journal of Geophysical Research 13, C11S03, 1-18.

Hernández Arana, H.E., Warwick, R.M., Attrill, M.J., Rowden, A.A., Gold-Bouchot, G., 2005. Assessing the impact of oil-related activities on benthic macrofauna assemblages of the Campeche shelf, southern Gulf of Mexico. Marine Ecology Progress Series 289, 89-107.

Kingston, P.F. 1987. Field effects of platform discharges on benthic macrofauna. Philosophical Transactions of Royal Society London B316, 545-555.

Kneib, R.D., Weeks, C.A., 1990. Intertidal distribution and feeding habits of the mud crab Eurytium limosum. Estuaries 13, 462-468.

Kröncke, I., 1995. Long-term changes in North Sea benthos. Senckenbergiana Maritima 26, 73-80.

Legendre, P., Legendre, L., 1998. Numerical Ecology: Developments in Environmental Modelling 20 ( $2^{\text {nd }}$ Edition). Elsevier Science B.V., The Netherlands.

Lindman, H.R., 1992. Analysis of variance in experimental design. Springer-Verlag, New York.

Love, M.S., Caselle, J., Snook, L., 1999. Fish assemblages on mussel mounds surrounding seven oil platforms in the Santa Barbara Channel and Santa Maria Basin. Bulletin of Marine Science $65,497-513$

Lu, L., Wu, R.S.S., 2000. An experimental study on recolonization and succession of marine macrobenthos in defaunated sediment. Marine Biology 136, 291-302.

Maggi, C., Trabucco, B., Mannozzi, M., Manfra, L., Gabellini, M., Di Mento, R., Nonnis, O., Virno 
Lamberti, C., Cicero, A.M., 2007. A methodology approach to study the environmental impact of oil and gas offshore platforms. Rapport de la Commission Internationale pour l'Exploration Scientifique de la Mer Méditerranée 38, 688.

Magi, E., Bianco, R., Ianni, C., Di Carro, M., 2002. Distribution of polycyclic hydrocarbons in the sediments of the Adriatic Sea. Environmental Pollution 119, 91-98.

Marini, M., Jones, B.H., Campanelli, A., Grilli, F., Lee, G.M., 2008. Seasonal variability and Po River plume influence on biochemical properties along western Adriatic coast. Journal of Geophysical Research 113, C05S90, doi:10.1029/2007JC004370.

McArdle, B.H., Anderson, M.J., 2001. Fitting multivariate models to community data: a comment on distance-based redundancy analysis. Ecology 82, 290-297.

Montagna P., Harper D.E. Jr., 1996. Benthic infaunal long-term response to offshore production platforms in the Gulf of Mexico. Canadian Journal of Fishery and Aquatic Sciences 53, 25672588.

Neira, F.J., 2005. Summer and winter plankton fish assemblages around offshore oil and gas platforms in south-eastern Australia. Estuarine, Coastal and Shelf Science 63, 589-604.

OGP. 2005. Facts, figures and expectations for the Green Paper on a European Maritime Policy. www. ogp.org.uk.

Olsgard, F., Gray, J.S., 1995. A comprehensive analysis of the effects of offshore oil and gas exploration and production on the benthic communities of the Norwegian continental shelf. Marine Ecology Progress Series 122, 277-306.

Olsgard, F., Somerfield, P.J., Carr, M.R., 1997. Relationships between taxonomic resolution and data transformations in analyses of a macrobenthic community along an established pollution gradient. Marine Ecology Progress Series 149, 173-181.

Page, H.M., Dugan, J.E., Dugan, D.S., Richards, J.B., Hubbard, D.M., 1999. Effects of an offshore oil platform on the distribution and abundance of commercially important crab species. Marine Ecology Progress Series 185, 47-57. 
1 Page, H.M., Dugan, J.E., Scroeder, D.M., Nishimoto M.M., Love, M.S., Hoesterey, J. C., 2007.

Trophic links and condition of a temperate reef fish: comparisons among offshore oil platform and natural reef habitats. Marine Ecology Progress Series 344, 245-256.

Pearson, T.H., Rosemberg, R., 1978. Macrobenthic succession in relation to organic enrichment and pollution of the marine environment. Oceanography and Marine Biology. An Annual Review $16,229-311$.

Peterson, C.H., Kennicutt, M.C., Green, R.H., Montagna, P., Harper, D.E., Powell, E.N., Roscigno, P.F., 1996. Ecological consequences of environmental perturbations associated with offshore hydrocarbon production: a perspective on long-term exposures in the Gulf of Mexico. Canadian Journal of Fishery and Aquatic Sciences 53, 2637-2654.

Pinder, D., 2001. Offshore oil and gas: global resource knowledge and technological change. Ocean and Coastal Management 44, 579-600.

Rabalais, N.N., McKee, B.A., Reed, D.J., Means, J.C., 1992. Fate and effects of produced water discharges in coastal Louisiana, Gulf of Mexico, USA. In: Ray, J.P., Engelhart, F.R. (Eds.), Produce water. Plenum Press, New York, pp. 355-369.

Simpson, H.E., 1949. Measurement of diversity. Nature 163, 688.

Spagnolo, A., Panfili, M., Giampieri, A., Spegne, R., Trovatelli, L., 2002. Cambiamenti indotti sulla comunità bentonica di fondo mobile da una piattaforma estrattiva offshore (Adriatico settentrionale). Biologia Marina Mediterranea 9, 191-198.

Spagnolo, A., Ausili, S., Fabi, G., Manoukian, S., Puletti, M., 2006. Realizzazione di una piattaforma estrattiva offshore: effetti sul macrozoobenthos di fondo mobile. Biologia Marina Mediterranea 13, 60-61.

Stachowitsch, M., Kikinger, R., Herler, J., Zolda, P., Geutebrück, E., 2002. Offshore oil platforms and fouling communities in the southern Arabian Gulf (Abu Dhabi). Marine Pollution Bulletin 44, 853-860.

Stanley, D.R., Wilson, C.A., 1997. Seasonal and spatial variation in the abundance and size 
distribution of fishes associated with a petroleum platform in the northern Gulf of Mexico. Canadian Journal of Fishery and Aquatic Sciences 54, 1166-1176.

Terlizzi, A., Bevilacqua, S., Scuderi, D., Fiorentino, D., Guranieri, G., Giangrande, A., Licciano, M., Felline, S., Fraschetti, S., 2008. Effects of offshore platforms on soft-bottom macrobenthic assemblages: A case study in a Mediterranean gas field. Marine Pollution Bulletin 56, 1303-1309.

Thayer, S.A., Haas, R.C., Douglas Hunter, R., Kushler, R.H., 1997. Zebra mussel (Dreissena polymorpha) effects on sediment, other zoobenthos, and the diet and growth of adult yellow perch (Perca flavescens) in pond enclosures. Canadian Journal of Fishery and Aquatic Sciences 54, 1903-1915.

Trabucco, B., Cicero, A.M., Gabellini, M., Virno Lamberti, C., Di Mento, R., Bacci, T., Moltedo, G., Tomassetti, P., Panfili, M., Marusso, V., Cornello, M., 2006. Studio del popolamento macrozoobentonico di fondo mobile in prossimità di una piattaforma offshore (Adriatico centrale). Biologia Marina Mediterranea 13, 659-662.

Trabucco, B., Bacci, T., Marusso, V., Lomiri, S., Vani, D., Marzialetti, S., Cicero, A.M., Di Mento, R., De Biasi, A.M., Gabellini, M., Virno Lamberti, C., 2008. Studio della macrofauna attorno alle piattaforme oo-shore in Adriatico centrale. Biologia Marina Mediterranea 15, 141-143.

Underwood, A.J., 1996. Detection, interpretation, prediction and management of environmental disturbances: Some roles for experimental marine ecology. Journal of Experimental Marine Biology and Ecology 200, 1-27.

Warburg, M.R., Schwartz, Y., 1993. Intra- and interspecific relationships within a crab community of the intertidal rocky shore in the Eastern Mediterranean. Proceedings of the fourth Colloquium Crustacea Decapoda Mediterranea. Bios, Macedonia, Greece 1, 33-47.

Wilson-Ormond, E.A., Elliss, M.S., Powell, E.N., Kim, Y., Li S-I., 2000. Effects of gas-producing platforms on continental shelf megafauna in the Northwest Gulf of Mexico: reproductive status and health. Int. Rev. Hydrobiologia 85, 299-323. 
1 Wolfson, A., VanBlaricom, G., Davis, N., Lewbel, G.S., 1979. The marine life of an offshore oil 2 platform. Marine Ecology Progress Series 1, 81-89.

3 Zariquiey Alvarez, R., 1968. Crustáceos decápodos ibéricos. Investigación Pesquera 32, 1-510. 


\section{$1 \quad$ Figure captions}

2 Fig. 1. Study area and position of the two investigated gas platforms, Barbara NW (pB) and Calipso 3 (pC).

4 Fig. 2. Univariate indices of macrofaunal communities at each distance (5, 30, 60, 120, and $1000 \mathrm{~m})$

5 for both $\mathrm{pB}$ and $\mathrm{pC}$ during the three monitoring years. $\mathrm{S}_{\mathrm{m}}=$ mean species richness (number of

6 species $\pm \mathrm{SD}$ ); $\mathrm{N}=$ mean abundance (number of specimens $0.105 \mathrm{~m}^{-2} \pm \mathrm{SD}$ ); $\lambda=$ mean Simpson 7 index $( \pm \mathrm{SD})$. 


\section{Table 1}

PERMANOVA analyzing differences among assemblages at increasing distance from platforms during the three monitoring years based on Gower exc 0-0 similarity

\begin{tabular}{|c|c|c|c|c|c|}
\hline Source of variability & d.f. & SS & MS & $F$ & $p$ \\
\hline Distance $=\mathrm{Di}$ & 4 & 15937.00 & 3984.20 & 0.94852 & 0.5665 \\
\hline Year $=$ Ye & 2 & 22416.00 & 11208.00 & 1.05590 & 0.5356 \\
\hline Platform = Pl & 1 & 44032.00 & 44032.00 & 30.77900 & 0.0001 \\
\hline Di x Ye & 8 & 15807.00 & 1975.90 & 1.00670 & 0.4865 \\
\hline Di x Pl & 4 & 16802.00 & 4200.40 & 2.93610 & 0.0001 \\
\hline Ye x Pl & 2 & 21230.00 & 10615.00 & 7.41980 & 0.0001 \\
\hline Di x Ye x Pl & 8 & 15702.00 & 1962.70 & 1.37190 & 0.0008 \\
\hline Residual & 210 & $3.0043 \mathrm{E} 5$ & 1430.60 & & \\
\hline
\end{tabular}

not significant $\mathrm{p}>0.05$; significant $0.05>\mathrm{p}>0.01$; highly significant $\mathrm{p}<0.01$ 
Table 2

PERMANOVA analyzing separately differences among assemblages at increasing distance from each platform during the three monitoring years

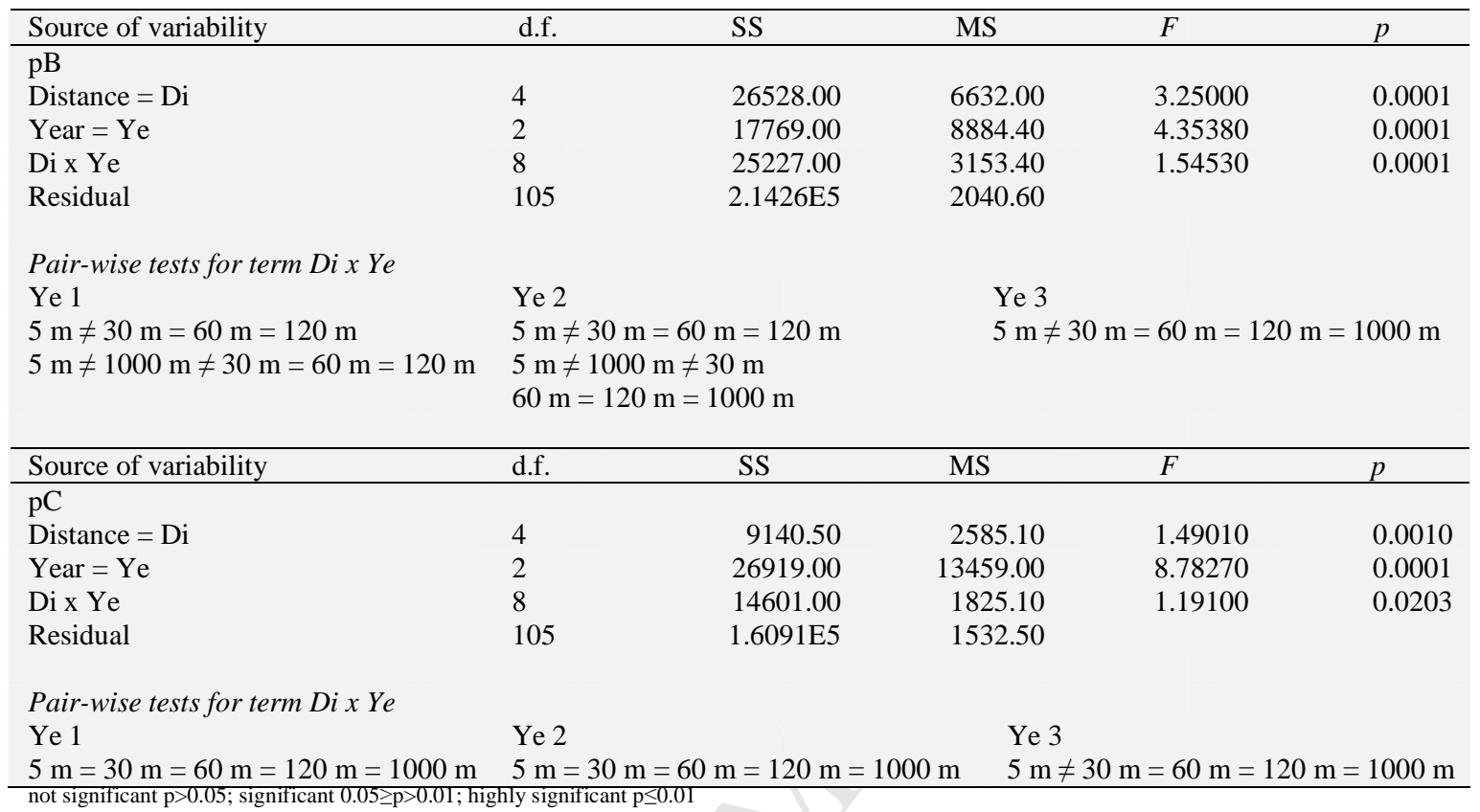




\section{Table 3}

Summary of SIMPER analysis for $\mathrm{pB}$ and $\mathrm{pC}$

\begin{tabular}{|c|c|c|c|c|c|c|c|c|c|c|c|}
\hline Species & Avg. ab. & $\begin{array}{c}\text { Contr. } \\
\%\end{array}$ & $\begin{array}{c}\text { Cum. } \\
\%\end{array}$ & $\begin{array}{l}\text { Avg. dis. } \\
\%\end{array}$ & & Species & Avg. ab. & $\begin{array}{c}\text { Contr. } \\
\%\end{array}$ & $\begin{array}{c}\text { Cum. } \\
\%\end{array}$ & $\begin{array}{l}\text { Avg. dis. } \\
\%\end{array}$ & \\
\hline $\begin{array}{l}\text { Distances across years } \\
\text { pB }\end{array}$ & & & & & & $\begin{array}{l}\text { Distances across years } \\
\text { pC }\end{array}$ & & & & & \\
\hline $5 \mathrm{~m}$ & & & & & & $5 \mathrm{~m}$ & & & & & \\
\hline Prionospio malmgreni & 0.51 & 12.15 & 12.15 & $5 \mathrm{~m}$ vs $30 \mathrm{~m}$ & 88.13 & Caulleriella caputesocis & 1.25 & 11.25 & 11.25 & $5 \mathrm{~m}$ vs $30 \mathrm{~m}$ & 65.98 \\
\hline Naticarius hebraeus & 0.52 & 9.50 & 21.65 & $5 \mathrm{~m}$ vs $60 \mathrm{~m}$ & 88.52 & Marphysa bellii & 0.81 & 9.52 & 20.77 & $5 \mathrm{~m}$ vs $60 \mathrm{~m}$ & 69.49 \\
\hline Solemya togata & 0.57 & 8.15 & 29.80 & $5 \mathrm{~m}$ vs $120 \mathrm{~m}$ & 89.57 & Sternaspis scutata & 0.80 & 8.38 & 29.15 & $5 \mathrm{~m}$ vs $120 \mathrm{~m}$ & 70.44 \\
\hline Myrtea spinifera & 0.72 & 6.83 & 36.63 & $5 \mathrm{~m}$ vs $1000 \mathrm{~m}$ & 89.74 & Prionospio cirrifera & 0.67 & 7.43 & 36.58 & $5 \mathrm{~m}$ vs $1000 \mathrm{~m}$ & 71.06 \\
\hline Galathea intermedia & 0.56 & 5.88 & 42.51 & $30 \mathrm{~m}$ vs $60 \mathrm{~m}$ & 61.20 & Hyala vitrea & 0.70 & 6.78 & 43.36 & $30 \mathrm{~m}$ vs $60 \mathrm{~m}$ & 57.64 \\
\hline Onuphis conchilega & 0.53 & 5.72 & 48.23 & $30 \mathrm{~m}$ vs $120 \mathrm{~m}$ & 64.21 & Cirratulus filiformis & 0.73 & 6.64 & 50.00 & $30 \mathrm{~m}$ vs $120 \mathrm{~m}$ & 58.67 \\
\hline $30 \mathrm{~m}$ & & & & $30 \mathrm{~m}$ vs $1000 \mathrm{~m}$ & 65.47 & $30 \mathrm{~m}$ & & & & $30 \mathrm{~m}$ vs $1000 \mathrm{~m}$ & 58.42 \\
\hline Callianassa subterranea & 0.88 & 10.28 & 10.28 & $60 \mathrm{~m}$ vs $120 \mathrm{~m}$ & 59.86 & Marphysa bellii & 1.33 & 23.49 & 23.49 & $60 \mathrm{~m}$ vs $120 \mathrm{~m}$ & 57.85 \\
\hline Capitella capitata & 0.89 & 9.75 & 20.73 & $60 \mathrm{~m}$ vs $1000 \mathrm{~m}$ & 60.00 & Hyala vitrea & 1.07 & 10.62 & 34.11 & $60 \mathrm{~m}$ vs $1000 \mathrm{~m}$ & 58.09 \\
\hline Onuphis conchilega & 0.91 & 8.92 & 28.95 & $120 \mathrm{~m}$ vs $1000 \mathrm{~m}$ & 62.38 & Lumbrineris impatiens & 0.68 & 8.37 & 42.48 & $120 \mathrm{~m}$ vs $1000 \mathrm{~m}$ & 56.49 \\
\hline Paralacydonia paradoxa & 0.79 & 7.68 & 36.63 & & & Tharyx marioni & 0.81 & 6.80 & 49.29 & & \\
\hline Nephtys hystricis & 0.79 & 6.74 & 43.37 & & & & & & & & \\
\hline Alpheus glaber & 0.66 & 6.64 & 50.01 & & & & & & & & \\
\hline $60 \mathrm{~m}$ & & & & & & $60 \mathrm{~m}$ & & & & & \\
\hline Callianassa subterranea & 1.12 & 13.46 & 13.46 & & & Marphysa bellii & 1.27 & 27.18 & 27.18 & & \\
\hline Nephtys hystricis & 1.13 & 13.39 & 26.85 & & & Hyala vitrea & 1.00 & 13.51 & 40.69 & & \\
\hline Capitella capitata & 0.94 & 8.38 & 35.23 & & & Callianassa subterranea & 0.71 & 8.57 & 49.26 & & \\
\hline Paralacydonia paradoxa & 0.94 & 8.09 & 43.32 & & & & & & & & \\
\hline Onuphis conchilega & 0.85 & 7.62 & 50.95 & & & & & & & & \\
\hline $120 \mathrm{~m}$ & & & & & & $120 \mathrm{~m}$ & & & & & \\
\hline Callianassa subterranea & 1.12 & 13.46 & 13.46 & & & Marphysa bellii & 1.13 & 21.25 & 21.25 & & \\
\hline Nephtys hystricis & 1.13 & 13.39 & 26.85 & & & Hyala vitrea & 1.10 & 16.21 & 37.45 & & \\
\hline Onuphis conchilega & 0.94 & 8.38 & 35.23 & & & Lumbrineris impatiens & 0.61 & 9.31 & 46.76 & & \\
\hline Paralacydonia paradoxa & 0.94 & 8.09 & 43.32 & & & Callianassa subterranea & 0.66 & 8.55 & 55.31 & & \\
\hline Capitella capitata & 0.85 & 7.62 & 50.95 & & & & & & & & \\
\hline $1000 \mathrm{~m}$ & & & & & & $1000 \mathrm{~m}$ & & & & & \\
\hline Nephtys hystricis & 1.39 & 23.54 & 23.54 & & & Marphysa bellii & 1.10 & 15.58 & 15.58 & & \\
\hline Callianassa subterranea & 1.31 & 19.88 & 43.42 & & & Hyala vitrea & 1.20 & 11.23 & 26.81 & & \\
\hline \multirow{3}{*}{ Capitella capitata } & 0.83 & 10.13 & 53.54 & & & Lumbrineris impatiens & 0.73 & 10.57 & 37.38 & & \\
\hline & & & & & & Callianassa subterranea & 0.93 & 10.14 & 47.52 & & \\
\hline & & & & & & Cirratulus filiformis & 0.67 & 7.37 & 54.89 & & \\
\hline
\end{tabular}




\section{Table 3}

Continue

\begin{tabular}{|c|c|c|c|c|c|c|c|c|c|c|c|}
\hline Species & Avg. ab. & $\begin{array}{c}\text { Contr. } \\
\%\end{array}$ & $\begin{array}{c}\text { Cum. } \\
\%\end{array}$ & $\begin{array}{c}\text { Avg. dis. } \\
\%\end{array}$ & & Species & Avg. ab. & $\begin{array}{c}\text { Contr. } \\
\%\end{array}$ & $\begin{array}{c}\text { Cum. } \\
\%\end{array}$ & $\begin{array}{l}\text { Avg. dis. } \\
\%\end{array}$ & \\
\hline $\begin{array}{l}\text { Years across distances } \\
\text { pB }\end{array}$ & & & & & & $\begin{array}{l}\text { Years across distances } \\
\mathrm{pC}\end{array}$ & & & & & \\
\hline $1^{\text {st }}$ year & & & & & & $1^{\text {st }}$ year & & & & & \\
\hline Callianassa subterranea & 0.83 & 12.78 & 12.78 & $1^{\text {st }}$ vs $2^{\text {nd }}$ year & 69.90 & Marphysa bellii & 0.86 & 30.44 & 30.44 & $1^{\text {st }}$ vs $2^{\text {nd }}$ year & 78.41 \\
\hline Nephtys hystricis & 0.75 & 12.47 & 25.25 & $1^{\text {st }}$ vs $3^{\text {rd }}$ year & 76.05 & Labidoplax digitata & 0.53 & 13.05 & 43.49 & $1^{\text {st }}$ vs $3^{\text {rd }}$ year & 79.03 \\
\hline Onuphis conchilega & 0.87 & 11.04 & 36.29 & $2^{\text {nd }}$ vs $3^{\text {rd }}$ year & 71.24 & Hyala vitrea & 0.62 & 11.45 & 54.94 & $2^{\text {nd }}$ vs $3^{\text {rd }}$ year & 60.37 \\
\hline Alpheus glaber & 0.52 & 6.44 & 42.74 & & & & & & & & \\
\hline Paralacydonia paradoxa & 0.60 & 6.38 & 49.12 & & & & & & & & \\
\hline $2^{\text {nd }}$ year & & & & & & $2^{\text {nd }}$ year & & & & & \\
\hline Nephtys hystricis & 1.08 & 12.62 & 12.62 & & & Marphysa bellii & 1.19 & 24.58 & 24.58 & & \\
\hline Callianassa subterranea & 1.09 & 11.99 & 24.61 & & & Lumbrineris impatiens & 0.90 & 15.40 & 39.98 & & \\
\hline Onuphis conchilega & 1.16 & 11.33 & 35.95 & & & Callianassa subterranea & 0.80 & 11.01 & 50.99 & & \\
\hline Capitella capitata & 0.89 & 9.06 & 45.01 & & & Hyala vitrea & 0.69 & 6.75 & 57.74 & & \\
\hline Paralacydonia paradoxa & 0.72 & 5.69 & 50.70 & & & & & & & & \\
\hline $3^{\text {rd }}$ year & & & & & & $3^{\text {rd }}$ year & & & & & \\
\hline Callianassa subterranea & 0.89 & 16.10 & 16.10 & & & Hyala vitrea & 1.73 & 15.48 & 15.48 & & \\
\hline Nephtys hystricis & 0.83 & 13.35 & 29.45 & & & Cirratulus filiformis & 1.55 & 13.13 & 28.61 & & \\
\hline Capitella capitata & 0.84 & 11.38 & 40.83 & & & Marphysa bellii & 1.33 & 11.76 & 40.38 & & \\
\hline
\end{tabular}

reaching the cumulative contribution of about $50 \%$ are reported. \% average dissimilarities (Avg. dis.) between distance and year groups are also pointed out. 


\section{Table 4}

Summary of 3-way ANOVA applied to mean values of mean species richness $\left(\mathrm{S}_{\mathrm{m}}\right)$, mean abundance $(\mathrm{N})$, and mean Simpson index $(\lambda)$ per each distance during the three monitoring years

\begin{tabular}{|c|c|c|c|c|c|c|c|c|c|c|}
\hline \multirow{2}{*}{$\begin{array}{l}\text { Source of } \\
\text { variability }\end{array}$} & \multirow[t]{2}{*}{ d.f. } & \multicolumn{3}{|l|}{$\mathrm{S}_{\mathrm{m}}$} & \multicolumn{3}{|l|}{$\mathrm{N}$} & \multicolumn{3}{|l|}{$\lambda$} \\
\hline & & MS & $F$ & $p$ & MS & $F$ & $p$ & MS & $F$ & $p$ \\
\hline Distance $=\mathrm{Di}$ & 4 & 56.16 & 1.66968 & 0.3158 & 0.33 & 2.72861 & 0.1772 & 0.09 & 4.5624 & 0.0015 \\
\hline Year $=$ Ye & 2 & 1005.65 & 2.74148 & 0.2673 & 4.14 & 1.87247 & 0.3481 & 0.34 & 16.4272 & 0.0001 \\
\hline Platform = Pl & 1 & 250.10 & 6.86101 & 0.0095 & 0.07 & 1.15466 & 0.2838 & 0.47 & 22.4301 & 0.0001 \\
\hline Di x Ye & 8 & 219.69 & 3.93937 & 0.0348 & 0.61 & 7.12767 & 0.0059 & 0.07 & 3.4380 & 0.0010 \\
\hline Di x Pl & 4 & 33.64 & 0.92271 & 0.4516 & 0.12 & 1.97517 & 0.0995 & 0.01 & 0.5387 & 0.7074 \\
\hline Yex Pl & 2 & 366.83 & 10.06308 & 0.0001 & 2.21 & 36.66851 & 0.0000 & 0.11 & 5.4710 & 0.0048 \\
\hline Di x Ye x Pl & 8 & 55.77 & 1.52983 & 0.1484 & 0.09 & 1.40891 & 0.1942 & 0.02 & 0.8098 & 0.5946 \\
\hline
\end{tabular}




\section{Table 5}

Summary of 2-way ANOVAs for $\mathrm{pB}$ and $\mathrm{pC}$ applied to mean values of mean species richness $\left(\mathrm{S}_{\mathrm{m}}\right)$, mean abundance $(\mathrm{N})$, and mean Simpson index $(\lambda)$ per each distance during the three monitoring years

\begin{tabular}{|c|c|c|c|c|c|c|c|c|c|c|}
\hline \multirow{2}{*}{$\begin{array}{l}\text { Source of } \\
\text { variability }\end{array}$} & \multirow[t]{2}{*}{ d.f. } & \multicolumn{3}{|c|}{$\mathrm{S}_{\mathrm{m}}$} & \multicolumn{3}{|c|}{$\mathrm{N}$} & \multicolumn{3}{|c|}{$\lambda$} \\
\hline & & MS & $F$ & $P$ & MS & $F$ & $P$ & MS & $F$ & $P$ \\
\hline \multicolumn{11}{|l|}{$\mathrm{pB}$} \\
\hline Distance $=\mathrm{Di}$ & 4 & 24.62 & 0.53140 & 0.7130 & 0.07 & 1.25200 & 0.2936 & 0.064 & 5.8516 & 0.0003 \\
\hline Year $=$ Ye & 2 & 158.31 & 3.41730 & 0.0365 & 0.54 & 9.49700 & 0.0002 & 0.036 & 3.2701 & 0.0419 \\
\hline Di x Ye & 8 & 183.33 & 3.95740 & 0.0004 & 0.26 & 4.56700 & 0.0001 & 0.023 & 2.1459 & 0.0377 \\
\hline \multicolumn{11}{|l|}{$\mathrm{pC}$} \\
\hline Distance $=\mathrm{Di}$ & 4 & 65.18 & 2.45220 & 0.0505 & 0.37 & 5.80900 & 0.0003 & 0.04 & 1.3678 & 0.250 \\
\hline Year $=$ Ye & 2 & 1214.18 & 45.68040 & 0.0000 & 5.82 & 90.44400 & 0.0000 & 0.42 & 13.7004 & 0.001 \\
\hline Di x Ye & 8 & 95.12 & 3.4659 & 0.0014 & 0.43 & 6.73900 & 0.0000 & 0.06 & 2.1160 & 0.041 \\
\hline
\end{tabular}

not significant $\mathrm{p}>0.05$; significant $0.05>\mathrm{p}>0.01$; highly significant $\mathrm{p}<0.01$

>> highly significant; > significant 


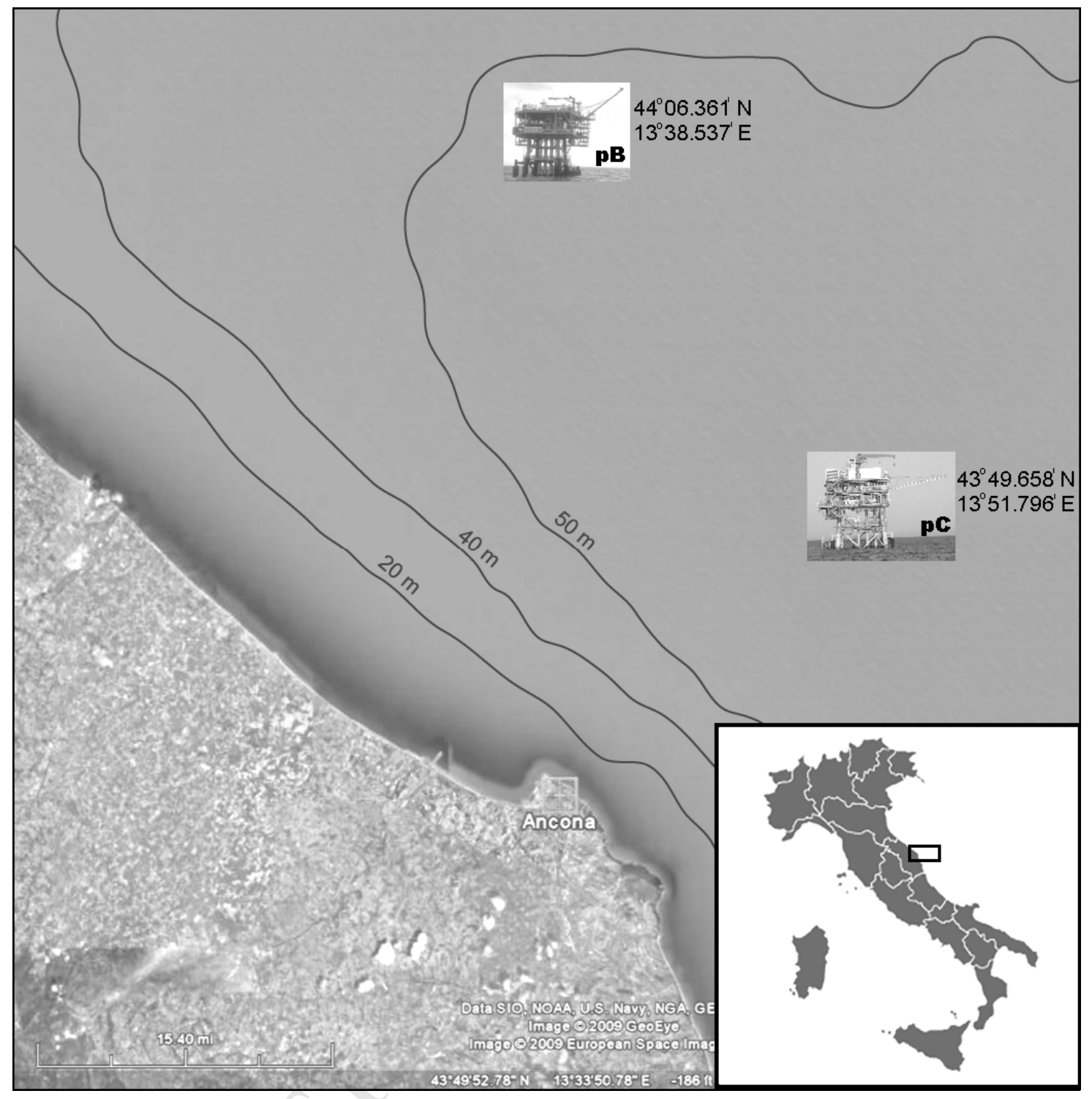



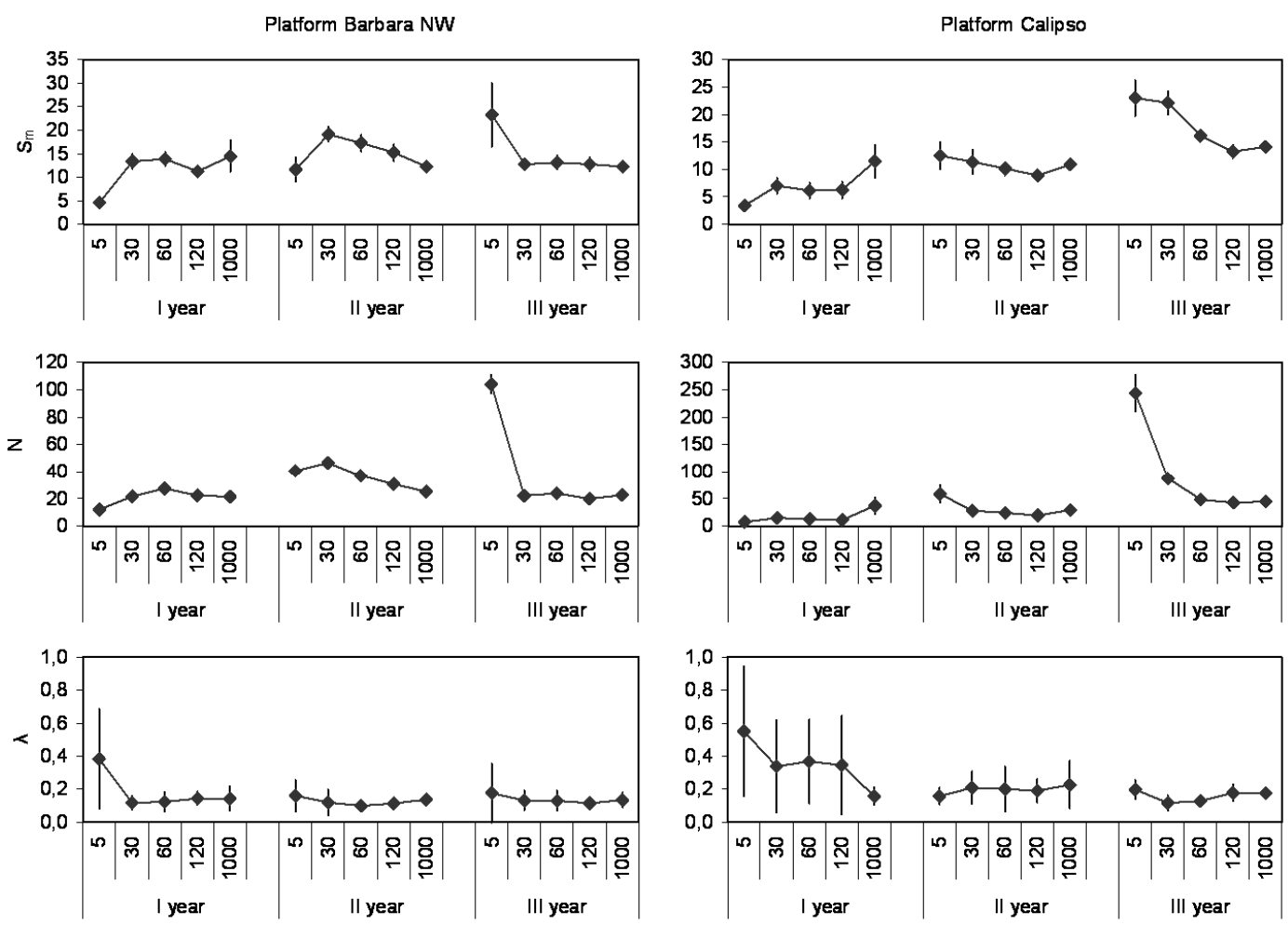